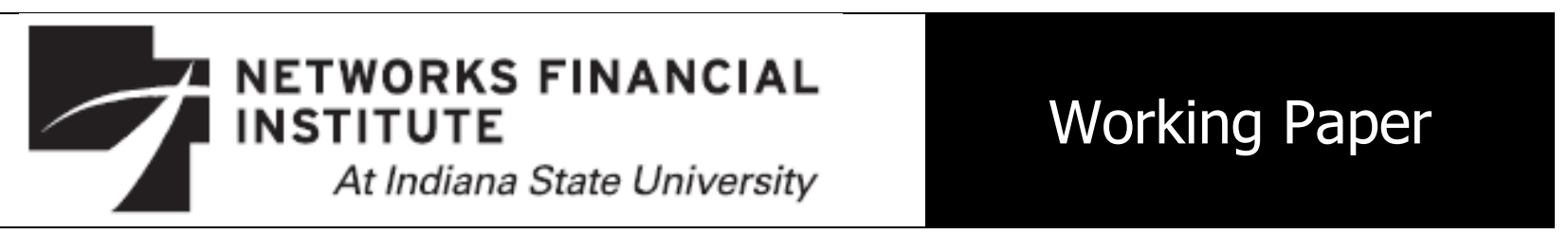

2011-WP-18

August 2011

\title{
Consumer Debt Delinquency over Life Cycle Stages
}

Jing Jian Xiao and Rui Yao

Abstract: Consumer debt delinquency, as measured by being 60 or more days late in debt payment, is an indicator of financial ill health. Using six datasets of the 1992-2007 U.S. Surveys of Consumer Finances, this study examines consumer debt delinquency over life cycle stages. Inspired by previous research (Du \& Kamakura, 2006), fifteen life cycle stages are defined by household head's age, marital status, and presence and age of children. Multivariate logistic results show that young couples and young singles with children aged 7 or older and middle aged singles with children aged 15 or older are found to have the highest risk of debt delinquency. Findings suggest that presence and age of children are important factors affecting consumer debt delinquency, which should be considered in public policies that aim to improve consumer financial well-being.

About the Authors: Dr. Jing Jian Xiao is Professor of Consumer Economics at the University of Rhode Island, teaching courses in consumer economics and finance. His consumer financial behavior and other research has been published extensively in prestigious journals and his book publications include Mathematics of Personal Financial Planning, Chinese Youth in Transition, and Handbook of Consumer Finance Research. He has served as the President and co-Program Chair of American Council on Consumer Interests, the President of Asian Consumer and Family Economics Association, and Program Chair and Proceedings Editor of the Association for Financial Counseling and Planning Education, among others. He is currently serving on the board of National Consumer League. He is the Editor-in-Chief of Journal of Family and Economic Issues and also serves on editorial boards of several other consumer economics and finance journals. He is the editor-in-chief of a new book series entitled International Series of Consumer Science. He received his B. S. and M. S. in economics from the Zhongnan University of Economics and Law in China, and a Ph.D. in consumer economics from Oregon State University. Rui Yao, Ph.D., CFP (tm), is an Assistant Professor in the Personal Financial Planning Department at the University of Missouri. Dr. Yao received her Ph.D. in Family Resource Management from The Ohio State University. Her research interests include financial risk tolerance, portfolio allocation, financial ratios, debt management, retirement preparation, and household consumption patterns. She has provided professional service to various conferences and journals and is a member of the American Council of Consumer Interests, the Association for Financial Counseling and Planning Education, and Kappa Omicron Nu National Honor Society.

Keywords: Consumer debt, debt delinquency, life cycle behavior, Survey of Consumer Finance.

The authors thank John Tatom and Martha Henn for their helpful comments on earlier versions of this paper. The views expressed are those of the individual author(s) and do not necessarily reflect official positions of Networks Financial Institute. Please address questions regarding content to Jing Jian Xiao at xiao@uri.edu. Any errors or omissions are the responsibility of the author(s). NFI working papers and other publications are available on NFI's website (www.isunetworks.org). Click "Thought Leadership" and then "Publications/Papers." 


\section{Consumer Debt Delinquency over Life Cycle Stages}

\section{Introduction}

Debt delinquency refers to late debt payment behavior, which would immediately result in lower credit scores, jeopardize opportunities to receive future consumer credit, and adversely affect consumer financial well-being (Getter, 2006; Lyons, 2003). More importantly, mass debt delinquency may affect the economy at the macro level. Excessive consumer debt might be one of major reasons that caused the recent recession in the U.S. (Lander, 2008). Financial deregulations started in early 1980s resulted in many financial innovations that provided more credit alternatives for consumers but, at the same time, also demanded a higher level of knowledge and skills for consumers to manage debts (Ryan, Trumbull, \& Tufano, 2010). Because of financial deregulations and innovations in the last three decades, consumers have had broader access to credit. Despite the advantages of consumer credit, broader access mainly decreases consumer financial well-being (Dynan, 2009). The increase in the number of delinquencies and bankruptcies has been dramatic (Lyons, 2003).

To keep a balance between providing adequate credit for consumers and ensuring consumers to control their debts, more research on consumer debt delinquency is needed. Previous research on debt delinquency focuses on influences of financial resources (Getter, 2003), marital status (Lyons \& Fisher, 2006), family types (Sun \& Xiao, 2007), and family hardships (McCloud \& Dwyer, 2011). This study focuses on life cycle stages and empirically estimated probabilities of debt delinquency among consumers at various life cycle stages. Consumer financial behavior over the lifespan is of interest to policy makers and researchers. This question can be tackled with economic models under the utility framework, but recent evidence from behavioral economics shows that consumers are irrational and do not follow many 
assumptions under the utility function. In addition, because of the cognitive limitations of consumers and uncertainty of economic environments, it is difficult to plan and predict behavior over the lifespan. An alternative research approach is to empirically investigate how consumers do over various lifecycle stages. Since longitudinal data with debt delinquency and other related information is limited, this study uses cross-section data to depict an overall picture of debt delinquency over life cycle stages with nationally representative data from the 1992-2007 Surveys of Consumer Finances. Cross-section data is imperfect, but the findings can shed light on this lifespan behavior. Results of this study will increase our understanding of consumer debt delinquency behavior and provide helpful information for policy makers and business professionals to better meet consumer needs.

\section{Previous Research on Consumer Debt Delinquency}

Descriptive statistics of consumer debt delinquent behavior measured by the share of households of a given type, with missing debt payments for 60 or more days in recent years, can be found in Federal Reserve Board staff papers using data from various Surveys of Consumer Finances (SCF) (e.g. Aizcorbe, Kennickell, \& Moore, 2003; Bucks, Kennickell, \& Moore, 2006; Bucks et al., 2009). The trend of this measure among debtor households has increased since early 1990s, from 6 percent in 1992 to 7.1 percent in 2007, with fluctuations. Using data from 19892007 SCF, Xiao and Yao (2011) find that the trend of the consumer debt delinquency rate has been stable at around 7.4 percent among debtor households. However, several family types, such as cohabiting with children and single mother families, have about twice, or more, the average delinquency rate, 16.9 percent and 14.7 percent, respectively.

Previous research demonstrates that debt delinquency is associated with factors related to life cycle stages. Using data from the 1983 SCF to examine factors affecting late payment 
behavior, Canner and Luckett (1990) find that missing any debt payment is associated with several variables related to life cycle stages, such as marital status, age, or number of children. Lyons and Fisher (2006) examined debt repayment behavior using data from 1991-1995 Panel Study of Income Dynamics (PSID). They find that divorced men and women are more likely than married individuals to default on debt payments. Using the 2004 SCF, Sun and Xiao (2007) find that variables related to life cycle stages affect debt delinquency behavior. Married couples with children and single females with children are more likely to be late in debt payments. Household head's age shows an inverse U-shape on the risk of debt default (McCloud \& Dwyer, 2011).

Two studies examine consumer debt holding over life cycle stages. Baek and Hong (2004) use data from the 1998 SCF to examine factors related to two types of consumer debts: installment debt and credit card debt. Results of the double-hurdle model show that life cycle stages significantly affect installment debt and credit card debt holdings and amounts. Yilmazer and DeVaney (2005) use data from the 2001 SCF to examine how the types and amounts of household debt change over the life cycle. Results show that the likelihood of holding each type of debt and the amount of each type of debt as a percentage to total assets decrease with age. Probit results show that several factors relate to life cycle stages, such as age, marital status, and retirement status, affect debt ownership. To our best knowledge, no previous research examined the potential effect of life cycle stage on debt delinquency behavior.

Economic characteristics have been found to contribute to the likelihood of being delinquent on debt. Getter (2003) uses 1998 SCF to study factors associated with debt delinquency behavior. In his study, delinquency is defined as having missed a debt payment. Logistic results show that the most important predictor of delinquency behavior is income shock 
("income unusually low compared to what you would expect in a 'normal' year"). In another study, per capita income reduces delinquency risk, number of children increases the risk and welfare income decreases delinquency risk for only divorced women, but not for divorced men (Lyons \& Fisher, 2006). McCloud and Dwyer (2011) use data from 2004 SCF to study the relationship between family hardships and financial troubles, including bankruptcy, default, and credit access. Logistic results show that family hardships including poor health, divorce, unemployment, and income disruption increase a household's likelihood to default in debt.

Debt default is not only an indicator of financial ill-being itself but also results in undesirable financial consequences, such as having a bad credit score, paying high interest rates, losing access to credit, filing bankruptcy, and other indicators of financial ill-health. Debt delinquent behavior is associated with having to pay high interest rates. For example, based on data from the 2004 SCF, Sun and Xiao (2007) found that 7.69 percent of debtor households who make payments on time reported paying higher than 20 percent interest rates, while 23.14 percent of debtors who were late in payments for two months or longer paid a similar rate of interest. Moorman and Garasky (2008) use data from 1991-1996 PSID to examine factors associated with the risk of filing bankruptcy. They find that having financial problems is positively associated with filing bankruptcy. Among financial problems reported by the respondents, the most common one is missed debt payments. Johnson (2005), using SCF data, treats late payment behavior as an independent variable to predict the credit card holding status. She finds that late payment behavior is a significant predictor of not holding a credit card. Also, late payment behavior is more likely to be practiced by new credit card holders who are younger, unmarried, and have a low income, low wealth, and more children. Another study (Demos and Center for Responsible Lending, 2005), surveying credit card use among low- and middle- 
income consumers nationwide, finds that seven out of ten households report using their credit cards as a safety net, for paying such things as car repairs, basic living expenses, medical expenses, and house repairs. About half of the households had missed a payment or were late with a payment in the last year, and nearly a quarter of households reported paying a late fee at least one or two times in the past year.

Based on previous research, this study advances knowledge on debt delinquency behavior in several aspects. First, this study focuses on debt delinquency behavior over life cycle stages. Also, this study uses an innovative definition of life cycle stages, adapted from one developed by a representive, longitudinal data of American households (Du \& Kamakura, 2006). Moreover, this study uses six datasets of the U.S. Survey of Consumer Finances from 1992 to 2007 to study consumer financial delinquency and, therefore, is more comprehensive in data and time scopes, compared with prior research.

\section{Theoretical Framework}

The life cycle hypothesis is used as a general framework for this research. Consumers strive to maximize their life cycle utility by making intertemporal consumption choices (Modigliani \& Brumberg, 1954; Modigliani 1986). In doing so, they need to overcome their credit constraints, especially when they are young (Attanasio \& Weber, 2010). From an economic perspective, consumers assume a desirable consumption level. At some life cycle stages, they may borrow to meet this desirable consumption level. Given resource levels, family composition may affect consumption and borrowing behaviors (Browning \& Crossley, 2001). Controlling for resource level, younger households should be more likely to be credit constrained than their middle-aged and old counterparts; as such, they may be more likely to experience financial difficulties that increase the chance of debt delinquency. Similarly, at a certain resource 
level, a household with children will have higher consumption needs that may result in a greater chance to engage in debt delinquency behavior than a childless household.

In the literature of consumer behavior over the life cycle, both descriptive and prescriptive approaches are used. The prescriptive approach uses the framework of a utility function under various assumptions, especially about constraints, to examine optimal consumer behaviors. The descriptive approach empirically examines actual consumer behavior. Among descriptive approaches, two broad lines of research exist: one using age as the focal independent variable, and the other using life cycle stage as the focal independent variable (for a review, see Xiao, Ford, \& Kim, 2011).

This study uses a descriptive approach based on life cycle stages. The life cycle stage approach has been used for studying consumer behavior since 1950s (Lansing \& Morgan 1955). Using the concept of family life cycle, previous studies have examined various types of consumer behavior, such as financial behavior (Lansing \& Kish 1957), entertainment (Hisrich \& Peters 1974), energy consumption (Fritzche 1981), expenditure (Wagner \& Hanna 1983; Wilkes 1995), and other issues (e.g., Redondo-Bellon, Royo-Vela, \& Aldas-Manzano 2001; Schaninger \& Danko 1993; Wells \& Gubar 1966). Previous research used different demographic variables such as gender, age, marital status, presence and age of children, and retirement status to construct family life cycle stages in various ways.

Unlike previous research that used life cycle stage as a focal variable, Du and Kamakura (2006) use an innovative approach, applying the first-order Markov process to data from the Panel Studies on Income Dynamics across 34 years and empirically estimated life cycle stages in the United States, which resulted in categorization of life cycle stages that reflect unique features of American families. Since SCF data are collected from American families and used in this 
study, we constructed life cycle stage categories in the spirit of the work by Du and Kamakura (2006).

\section{Method}

Data

Data used in this study are from six data sets, 1992, 1995, 1998, 2001, 2004, and 2007 Survey of Consumer Finances (SCF), with a combined sample size of 25,889 . The earlier crosssectional datasets of SCF are excluded from this study because 1992 was the first year that the SCF collected information on income shock. The triennial survey is sponsored by the Federal Reserve Board and has comprehensive information about family finances. The survey provides information on family financial situations such as income, pension, assets, and debts. This survey also includes information about family demographic characteristics and their perceptions (Bucks et al., 2009).

\section{Variables}

The dependent variable is debt delinquency, which is measured by being 60 or more days late in debt payment. This measure was used to measure debt burdens in previous research (e.g. Bucks et al. 2009; Xiao \& Yao, 2011).

The focal independent variable, life cycle stage, is developed based on an innovative work by Du and Kamakura (2006) with adjustments. Unlike previous studies on life cycle stages that first conceptually categorize life cycle stages and then use data to fit these categories, $\mathrm{Du}$ and Kamakura directly estimate life cycle stages among American families using a long time period of longitudinal data set, the 1968-2001 Panel Study of Income Dynamics. They estimate the proposed life-cycle model, specifying up to 15 life cycle stages. On the basis of the Bayesian information criterion, they chose the solution with 13 stages. The stages they found are below: 
1. $\mathrm{Co} / \mathrm{So}=$ single or young couple with no child,

2. $\mathrm{C} 1=$ small household (couple) with children $<7$ years of age,

3. C2 = large household (couple) with children $<15$ years of age,

4. C3 = large household (couple) with older children,

5. $\mathrm{C} 4=$ small household (couple) with children $<15$ years of age,

6. $\mathrm{S} 1=$ single/divorced with no child,

7. $\mathrm{C} 5=$ small household with older children,

8. C6 = empty nest couple,

9. $\mathrm{S} 2=$ single/divorced with children $<15$ years of age,

10. S3 = divorced/widow with older children,

11. S5 = widowed empty nest,

12. $\mathrm{S} 4$ = divorced/single empty nest, and

13. $\mathrm{C} 7=$ retired/old couple with adult dependents.

Factors involved in these stages include marital status, presence of children, age of children, family size, and adult dependent status. In addition, age of the respondents is an implied factor in these categories. For example, stage 11 implied a stage of old age. The 13 life cycle stages proposed by Du and Kamakura (2006) are specific to the data they use. Some of the criteria are not definitive (e.g. young couple, small household) and the criteria used to define the stages are not consistent. Inspired by their work, the following factors are considered in this study, such as age, marital status, presence of children, age of children, and presence of financial dependents. The life cycle stage variable is developed using a systematic method. First, the sample is categorized into three age groups (under 35, 35-64, and 65 or older). Next, each age group is divided into two groups based on the respondent's marital status (married or unmarried). Finally, each age-marriage specific stage is further separated into three groups based on presence and age of children in the young and middle aged group, and presence of financial independents in the old group. As a result, 15 mutually exclusive life cycle stage categories are created for the use of this study. In other words, this life cycle variable has 15 categories below:

1. Age $<=35$, unmarried, no children,

2. Age $<=35$, unmarried, with children $<7$,

3. Age $<=35$, unmarried, with children $>=7$,

4. Age $<=35$, married (and cohabiting), no children, 
5. Age $<=35$, married, with children $<7$,

6. Age $<=35$, married, with children $>=7$,

7. Age 36-64, unmarried, no children,

8. Age 36-64, unmarried, with children $<15$,

9. Age 36-64, unmarried, with children $>=15$,

10. Age 36-64, married, no children,

11. Age 36-64, married, with children $<15$,

12. Age 36-64, married, with children $>=15$,

13. Age $>=65$, unmarried,

14. Age $>=65$, married, no financial dependents, and

15. Age $>=65$, married, with financial dependents.

The weighted distribution of these life cycle stages is presented in Table 1. Based on the literature, we include several control variables. One variable is about income shock. Getter (2003) finds that income shock (income is lower than normal years) affects debt delinquent behavior. Another variable is public assistance income. Lyons and Fisher (2006) find that, among divorced women, income from public assistance reduces the chance of debt delinquency. Based on previous research (Getter, 2003; Lyons \& Fisher, 2006, Sun \& Xiao, 2007), we also include several other control variables such as household head's education, race, employment status, health, homeownership, holding of several debts (mortgage, credit card, purchase, student loan, and vehicle loan debt), log household annual income and log household financial asset. In addition, survey year is also included as an independent variable to examine the trend of debt delinquent behavior.

\section{Data Analyses}

A bivariate analysis, a cross-tabulation of life cycle stages and debt delinquency status, is conducted to examine the percent distribution of delinquency across the life cycle stages. A multivariate logistic regression model is used to determine at which life cycle stages are households more likely to be delinquent and to predict the probabilities of households in debt delinquency at each life cycle stage. 
One unique feature of the SCF is that it includes five implicates that are five copies of data in a certain year of the survey, produced using sophisticated statistic procedures (Kennickell, 1998). All five implicates provided by the datasets are combined into a single dataset for analysis and the "repeated-imputation inference" method is used to obtain the coefficients, standard deviations, and log odds, which are more accurate than the results calculated based on one implicate (Kennickell, 1998). In addition, following the practices of many researchers who use SCF data, the weighted sample is used in bivariate analyses and the unweighted sample is used in multivariate logistic analyses.

\section{Results}

Table 2 presents results of bivariate analyses. On average, 5.6 percent of the respondents among American households are delinquent on debt. Five life cycle stages have much higher risks of delinquency than average. Young couples with children aged 7 or older have the highest risk, 14.9 percent, followed by young singles with children aged 7 or older (14.1 percent), young singles with children under 7 (12.5 percent), middle-aged singles with children aged 15 or older (10.8 percent), and middle-aged singles with children under 15 (10.4 percent).

Logistic analyses show that, compared with young couples without children, seven life cycle stages have statistically higher risk of debt delinquency (Table 3). Compared with young couples without children (the reference category), young couples with children aged 7 or older are 3.6 times as likely to be delinquent on debt (odds ratios $=3.589$ ). Other life cycle stages that have higher risks of debt delinquency include, in the order from high to low odds ratios (OR): middle-aged singles with children aged 15 or older $(\mathrm{OR}=2.077)$, young singles with children aged 7 or older $(\mathrm{OR}=2.010)$, middle-aged singles with children under $15(\mathrm{OR}=1.863)$, middleaged couples with children under $15(\mathrm{OR}=1.834)$, young couples with children under 7 
$(\mathrm{OR}=1.793)$, and middle-aged singles without children $(\mathrm{OR}=1.563)$.

Several control variables also have significant effects on debt delinquency. Having credit card debt, mortgage, purchase loans and student loans increase the risk of debt delinquency (Table 3). Consistent with Getter (2003), experiencing an adverse income shock increases the risk of debt delinquency. Other risk factors associated with debt delinquency include reporting poor health, being black, and having some college education (vs. lower than high school education). Controlling for other factors, respondents surveyed in 2004 are more likely to be delinquent on debt than respondents surveyed in 1992. Factors associated with lower probabilities of delinquency risk include financial asset and home ownership, which is consistent with previous research (Getter, 2003). Having vehicle loans also reduces debt delinquency risk. Using public assistance does not show effects on debt delinquency, which is partially consistent with previous research (Lyons \& Fisher, 2006).

Predicted probabilities of debt delinquency by life cycle stages (using modal or mean values of control variables) are presented in Figure 1 (see the footnote of Figure 1 for details on which variables use modes and which use means). Young couples with young children have the highest estimated risk of being debt delinquent, 8.6 percent, almost 3 percentage points higher than the second highest risk group. Other higher risk life cycle stages include middle aged singles with children age 15 or older (Risk Probability=5.0 percent), old couples with financial dependents ( 4.8 percent), young singles with children age 7 or older ( 4.8 percent), middle aged singles with children under 15 (4.5 percent), middle aged couples with children under 15 (4.4 percent), and young couples with young children under 7 (4.3 percent).

Results from the simulation analysis are used to construct various hypothetical life cycle stage trajectories. For example, a hypothetical trajectory of life cycle stages is presented in 
Figure 2. According to this simulation, when a single without children gets married before having children, the risk of delinquency decreases from 3.0 percent to 2.4 percent. When the head gets married and the household has young children, the delinquency risk increases to a much higher level (4.3 percent). This risk reaches the peak of 8.6 percent, when their children are at age 7 or older. When the household enters middle age and when children are under 15 , the risk decreases to 4.4 percent. The risk of delinquency goes down further to 3.4 percent when children reach age 15 or older. When the household enters old age (65 or older) with financial dependents (perhaps adult children or parents), the risk rises to 4.8 percent. The risk drops to 1.4 percent when the household reaches empty nest and increases a little when the household head becomes single (assuming they are widowed by then). Charts like this can be obtained based on the logistic results to construct different trajectories by assuming various combinations of age, marriage, and child presence and age categories. These charts may not represent the real situations, since they are not based on longitudinal data, but provide clues on debt delinquent behavior over lifespan. These charts can also be used for educational purposes.

To highlight the effects of age, marriage and child status on debt delinquency, additional charts based on the equation estimates are constructed. Note that these charts are selected for demonstration purposes; they are not comprehensive and exhaustive, covering all possible situations. Figure 3 shows the age effect on debt delinquency. Among childless singles, the middle age group has the highest risk of debt delinquency (3.8 percent), the young have the second highest risk (3.0 percent), and the old have the lowest risk (1.7 percent). Among childless couples, the patterns are the same (a reverse $U$ shape by age), while magnitudes of risks are smaller.

Figures 4 and 5 display the effect of child presence on debt delinquency. Figure 4 shows 
the delinquency risk of young households. For both married and single households, presence of children increase the risk of debt delinquency. For example, childless couples have a risk of 2.4 percent, couples with children under 7 have a risk of 4.3 percent, and couples with children aged 7 or older have the highest risk of 8.6 percent. The singles show the same pattern, but smaller risk magnitudes. Figure 5 shows the delinquency risk of middle aged households. Middle aged couples and singles show the same pattern in terms of presence of children; both childless couples and childless singles have the lowest risk rate compared with their counterparts with children. Married households with children under 15 have the highest risk rate, while unmarried household with children aged 15 or older have the highest risk rate in their group.

The potential effect of children's age on debt delinquency risk is presented in Figure 6. Married and unmarried households show different patterns. Young married households with children aged 7 or older have the highest risk of debt delinquency, while middle aged unmarried households with children age 15 or older have the highest risk of debt delinquency among each of their corresponding groups. Figure 7 shows the effect of marital status. The patterns of debt delinquency are the same among three age groups. Single headed households have a higher risk of debt delinquency than married households do. For example, the risk rate of debt delinquency for middle aged childless singles is 3.8 percent, while the rate for middle aged childless couples is 3.0 percent.

\section{Discussion}

This study examines debt delinquent risk by life cycle stages using data from 1992-2007 Surveys of Consumer Finances. Based on the innovative work of Du and Kamakura (2006), 15 family life cycle stages, representative of the population of American households, are constructed for the purpose of this study. Findings show that households at different life cycle stages have 
different probabilities of being delinquent on debt. Among household life cycle stage categories, the three that are most likely to be delinquent are young couples with children aged 7 or older, young singles with children aged 7 or older, and middle aged singles with children aged 15 or older.

The findings suggest that younger households are more financially distressed than their older counterparts. All three old groups have low rates of debt delinquency, based on the bivariate results. Two out of three old groups are less likely to be debt delinquent than seven young and middle aged groups based on multivariate results. However, the middle-aged groups are not less likely than their younger counterparts to be debt delinquent as predicted by theory. Four out of six middle-aged groups are more likely than average to be delinquent based on bivariate analyses. Four middle-aged groups are more likely than young couples without children to be late in debt payment.

Presence of children seems to be another important factor contributing to debt delinquency. Seven of nine groups with higher than average risk of delinquency in bivariate analysis have children in the household. Six out of seven life cycle stage groups in logistics analyses that have higher risk than young couples without children are those with children.

Our findings also suggest that marriage may influence the risk of debt delinquency. Three groups of married households and six groups of unmarried households have a higher than average risk of debt delinquency, according to bivariate analyses. Logistic analyses show that among several household types that have higher risks of debt delinquency than the reference category (young couples without children), three are married and four are unmarried household types. Simulation analyses also confirm that married households have lower risks of debt delinquency than singles. The effect of marriage on debt delinquency may be explained by 
economic resource levels. Previous research shows married households are financially better off than unmarried households (Hirschl, Altobelli, \& Rank, 2003) and that married households may have more resources to reduce the risk of debt delinquency.

This study is limited to analyses of cross-section data that generate results to describe patterns of debt delinquent behavior by life cycle stage categories. To answer debt delinquency behavior over life cycle stages, longitudinal data should be examined. However, national longitudinal datasets with debt delinquency and related financial and other control variables are limited. In addition, even if longitudinal data were available, demonstration of true lifespan behavior trajectories would face many methodological challenges. Thus, findings based on crosssection data, such as these here, can provide insights to understand family debt behavior over family life cycle stages.

The findings have implications for public policies. Policy makers should beware that life cycle stage is an important factor in debt delinquency. Special policy attention should be given to households with dependent children, because these households have a higher tendency to be delinquent on their loans. For example, households with children in three life cycle stage categories have much higher than average risk of debt delinquency and need to be considered specifically when public policies are made. In addition, the increased likelihood of debt delinquency amongst households with dependent children may influence policies concerning related social welfare safety nets. Finally, policy makers need to mobilize social resources to develop consumer education programs which improve knowledge about debts, skills to manage debts, and responsibilities to keep debts under control, and tailor education programs to meet various needs of households at different life cycle stages.

The results can also be used by financial educators. As demonstrated in the result section, 
simulations can be made and charts showing hypothetic life cycle stage trajectories can be constructed to demonstrate risky household types across various life cycle stages. In addition, findings of this research provide information for educators to target high risky households at certain life cycle stages and provide needed information about undesirable consequences of debt delinquency and how to avoid debt troubles and better manage their debts. 


\section{References}

Aizcorbe, A. M., Kennickell, A. B., \& Moore, K. B. (2003). Recent changes in U.S. family finances: Evidence from the 1998 and 2001 survey of consumer finances. Federal Reserve Bulletin (January), 1-32.

Attanasio, O. P. \& Weber, G. (2010). Consumption and saving: Models of intertemporal allocation and their implications for public policy. Journal of Economic Literature 48 (September), 693-751.

Baek E. \& Hong, G.-S. (2004). Effects of family life-cycle stages on consumer debts. Journal of Family and Economic Issues 25(3), 359-385.

Browning, M. \& Crossley, T. F. (2001). The life-cycle model of consumption and saving. Journal of Economic Perspectives 15(3), 3-22.

Bucks, B. K., Kennickell, A. B., \& Moore, K. B. (2006). Recent changes in U.S. family finances: Evidence from the 2001 and 2004 Survey of Consumer Finances. Federal Reserve Bulletin, A1-A38.

Bucks, B. K., Kennickell, A. B., Mach, T. L., \& Moore, K. B. (2009). Changes in U.S. family finances from 2004 to 2007: Evidence from the Survey of Consumer Finances. Federal Reserve Bulletin (February), A1-A55.

Canner, G. B. \& Luckett, C. A. (1990). Consumer debt repayment woes: Insights from a household survey. Journal of Retail Banking 12(1), 55-62.

Demos and Center for Responsible Lending (2005). The plastic safety net: The reality behind debt in America - Findings from a national household survey of credit card debt among lowand middle-income households. New York: Authors. http://www.responsiblelending.org/credit-cards/research-analysis/DEMOS-101205.pdf. 
Du, R. Y. \& Kamakura, W. A. (2006). Household life cycles and lifestyles in the United States. Journal of Marketing Research, 43 (February), 121-132.

Dynan, K. E. (2009). Changing household financial opportunities and economic security. Journal of Economic Perspectives 23(4), 49-68.

Fritzche, D. J. (1981). An analysis of energy consumption patterns by stage of family life cycle. Journal of Marketing Research 18 (May), 227-32.

Getter, D. E. (2003). Contributing to the delinquency of borrowers. Journal of Consumer Affairs 37 (July), 86-100.

Getter, D. E. (2006). Consumer credit risk and pricing. Journal of Consumer Affairs 40(1), 4163.

Hirschl, T. A., Altobelli, J., \& Rank, M. R. (2003). Does marriage increase the odds of affluence? Exploring the life course probabilities. Journal of Marriage and Family 65 (November), 927-938.

Hisrich, R. D. \& Peters, M. P. (1974). Selecting the superior segmentation correlate. Journal of Marketing 38 (July), 60-63.

Johnson, K. W. (2005). Recent development in the credit card market and the financial obligations ration. Federal Reserve Bulletin (Autumn), 473-486.

Kennickell, A. B. (1998). Multiple imputation in the Survey of Consumer Finances. Federal Reserve Board SCF Working Paper. Retrieved May 9, 2011 from http://www.federalreserve.gov/pubs/oss/oss2/method.html.

Lander, D. A. (2008). Regulating consumer lending. In J. J. Xiao (ed.). Handbook of Consumer Finance Research. NY: Springer. 387-410. 
Lansing, J. B. \& Kish, L. (1957). Family life cycle as an independent variable. American Sociological Review 22 (October), 512-19.

Lansing, J. B. \& Morgan, J. N. (1955). Consumer finances over the life cycle. In L. H. Clark (ed.). Consumer Behavior, Vol. 2. NY: New York University Press. 36-51.

Lyons, A. C. (2003). How credit access has changed over time for U.S. households. Journal of Consumer Affairs 37(2), 231-255.

Lyons, A. C. \& Fisher, J. (2006). Gender differences in debt repayment problems after divorce. Journal of Consumer Affairs 40 (December), 324-346.

McCloud, L. \& Dwyer, R. E. (2011). The fragile American: Hardship and financial troubles in the 21 st century. Sociological Quarterly 52, 13-35.

Modigliani, F. (1986). Life cycle, individual thrift, and the wealth of nations. American Economic Review 76(3), 297-313.

Modigliani, F. \& Brumberg, R. (1954). Utility analysis and the consumption function: An interpretation of cross-section data. In K. K. Kurihara (ed.). Post Keynesian Economics. New Brunswick: Rutgers University Press. 388-436.

Moorman, D. C. \& Garasky, S. (2008). Consumer debt repayment behavior as a precursor to bankruptcy. Journal of Family and Economic Issues 29, 219-33.

Redondo-Bellon, I., Royo-Vela, M., \& Aldas-Manzano, J. (2001). A family life cycle model adapted to the Spanish environment. European Journal of Marketing 35 (June), 612-38.

Ryan, A., Trumbull, G., \& Tufano, P. (2010). A brief postwar history of U. S. consumer finance. Finance Working Paper No. 11-058, Harvard Business School.

Schaninger, C. M. \& Danko, W. D. (1993). A conceptual and empirical comparison of alternative household lifecycle models. Journal of Consumer Research 19 (March), 580-94. 
Sun, J. \& Xiao, J. J. (2007). Economic and demographic differences in debt delinquent behavior. Consumer Interest Annual. Retrieved May 8, 2011 from http://www.thefreelibrary.com/Economic+and+demographic+differences+in+debt+delinque nt+behavior.-a0167842516.

Wagner, J. \& Hanna, S. (1983). The effectiveness of family life cycle variables in consumer expenditure research. Journal of Consumer Research 10 (September), 281-91.

Wells, W., \& Gubar, G. (1966). Life cycle concept in marketing research. Journal of Marketing Research 3 (November), 355-63.

Wilkes, R. E. (1995). Household lifecycle stages, transitions and product expenditures. Journal of Consumer Research 22 (June), 27-42.

Xiao, J. J., Ford, M., \& Kim, J. (2011). Consumer financial behavior: An interdisciplinary review of selected theories and research. Family and Consumer Science Research Journal 39(4), 399-414.

Xiao, J. J., \& Yao, R. (2011). Debt holding and burden by family structure: Patterns and trends in 1989-2007. Networks Financial Institute Working Paper 2011-WP-04. Retrieved March 12, 2011 from http://papers.ssrn.com/sol3/papers.cfm?abstract_id=1799362.

Yilmazer, T., \& DeVaney, S. A. (2005). Household debt over the life cycle. Financial Services Review 14(4), 285-304. 
Table 1: Distribution of Life-Cycle Stages

\begin{tabular}{lcc}
\hline Life stages & Count & Percent \\
\hline Age $<=35$, married (and cohabiting), no children & 1,216 & $4.7 \%$ \\
Age $<=35$, married, with children $<7$ & 2,077 & $8.0 \%$ \\
Age $<=35$, married, with children $>=7$ & 477 & $1.8 \%$ \\
Age $<=35$, unmarried, no children & 1,865 & $7.2 \%$ \\
Age $<=35$, unmarried, with children $<7$ & 607 & $2.3 \%$ \\
Age $<=35$, unmarried, with children $>=7$ & 334 & $1.3 \%$ \\
Age 36-64, married, no children & 3,288 & $12.7 \%$ \\
Age 36-64, married, with children $<15$ & 3,294 & $12.7 \%$ \\
Age 36-64, married, with children $>=15$ & 2,148 & $8.3 \%$ \\
Age 36-64, unmarried, no children & 3,249 & $12.5 \%$ \\
Age 36-64, unmarried, with children $<15$ & 685 & $2.6 \%$ \\
Age 36-64, unmarried, with children $>=15$ & 1,097 & $4.2 \%$ \\
Age $>=65$, married, no financial dependents & 2,504 & $9.7 \%$ \\
Age $>=65$, married, with financial dependents & 175 & $0.7 \%$ \\
Age $>=65$, unmarried & 2,873 & $11.1 \%$ \\
\hline
\end{tabular}

Note: Sample size $=25,889$. Weighted analysis on data from 1992-2007 Surveys of Consumer Finance. 
Table 2: Debt Delinquency by Life-Cycle Stages

\begin{tabular}{|c|c|c|}
\hline Life stages & Not Delinquent & Delinquent \\
\hline All families & $94.4 \%$ & $5.6 \%$ \\
\hline Age $<=35$, married and cohabiting, no children & $94.6 \%$ & $5.4 \%$ \\
\hline Age $<=35$, married, with children $<7$ & $91.7 \%$ & $8.3 \%$ \\
\hline Age $<=35$, married, with children $>=7$ & $85.1 \%$ & $14.9 \%$ \\
\hline Age $<=35$, unmarried, no children & $92.5 \%$ & $7.5 \%$ \\
\hline Age $<=35$, unmarried, with children $<7$ & $87.5 \%$ & $12.5 \%$ \\
\hline Age $<=35$, unmarried, with children $>=7$ & $85.9 \%$ & $14.1 \%$ \\
\hline Age 36-64, married, no children & $96.5 \%$ & $3.6 \%$ \\
\hline Age 36-64, married, with children $<15$ & $93.9 \%$ & $6.1 \%$ \\
\hline Age 36-64, married, with children $>=15$ & $95.0 \%$ & $5.0 \%$ \\
\hline Age 36-64, unmarried, no children & $94.2 \%$ & $5.8 \%$ \\
\hline Age 36-64, unmarried, with children $<15$ & $89.6 \%$ & $10.4 \%$ \\
\hline Age 36-64, unmarried, with children $>=15$ & $89.2 \%$ & $10.8 \%$ \\
\hline Age $>=65$, married, no financial dependents & $99.0 \%$ & $1.0 \%$ \\
\hline Age $>=65$, married, with financial dependents & $94.8 \%$ & $5.2 \%$ \\
\hline Age $>=65$, unmarried & $98.6 \%$ & $1.4 \%$ \\
\hline
\end{tabular}


Table 3: Logistic Results on Consumer Financial Delinquency

\begin{tabular}{|c|c|c|c|}
\hline Parameter & Coefficients & & $\begin{array}{l}\text { Odds } \\
\text { Ratio }\end{array}$ \\
\hline Intercept & -2.6324 & & \\
\hline \multicolumn{4}{|c|}{ Life Stages (Reference Category: Age $<=35$, married, no children) } \\
\hline Age $<=35$, married, with children $<7$ & 0.5838 & $* *$ & 1.793 \\
\hline Age $<=35$, married, with children $>=7$ & 1.2779 & $* * *$ & 3.589 \\
\hline Age $<=35$, unmarried no children & 0.2109 & & 1.235 \\
\hline Age $<=35$, unmarried, with children $<7$ & 0.4084 & & 1.504 \\
\hline Age $<=35$, unmarried, with children $>=7$ & 0.6982 & $* *$ & 2.010 \\
\hline Age 36-64, married, no children & 0.2062 & & 1.229 \\
\hline Age $36-64$, married, with children $<15$ & 0.6063 & $* * *$ & 1.834 \\
\hline Age $36-64$, married, with children $>=15$ & 0.3409 & & 1.406 \\
\hline Age 36-64, unmarried, no children & 0.4468 & $*$ & 1.563 \\
\hline Age $36-64$, unmarried, with children $<15$ & 0.6220 & $* *$ & 1.863 \\
\hline Age 36-64, unmarried, with children $>=15$ & 0.7307 & $* * *$ & 2.077 \\
\hline Age $>=65$, married, no financial dependents & -0.5558 & & 0.574 \\
\hline Age $>=65$, married, with financial dependents & 0.6873 & & 1.988 \\
\hline Age $>=65$, unmarried & -0.3603 & & 0.697 \\
\hline \multicolumn{4}{|l|}{ Survey Year (Reference Category: 1992) } \\
\hline 1995 & 0.0829 & & 1.086 \\
\hline 1998 & 0.3006 & & 1.351 \\
\hline 2001 & 0.3242 & & 1.383 \\
\hline 2004 & 0.4446 & $*$ & 1.560 \\
\hline 2007 & 0.1745 & & 1.191 \\
\hline \multicolumn{4}{|c|}{ Education (reference category=Less than High School Diploma) } \\
\hline High School Diploma/GED & 0.1082 & & 1.114 \\
\hline Some College & 0.3037 & $* *$ & 1.355 \\
\hline Bachelor's Degree & -0.0957 & & 0.909 \\
\hline Graduate/Professional Degree & -0.0913 & & 0.913 \\
\hline \multicolumn{4}{|l|}{ Race (reference category=White) } \\
\hline Black & 0.2407 & $* *$ & 1.272 \\
\hline Hispanic & -0.2048 & & 0.815 \\
\hline Other & -0.0851 & & 0.918 \\
\hline \multicolumn{4}{|l|}{$\begin{array}{l}\text { Employment Status (reference category=Salary } \\
\text { Earner) }\end{array}$} \\
\hline Self-employed & -0.0061 & & 0.994 \\
\hline Retired & -0.2186 & & 0.804 \\
\hline Not Currently Working & -0.1904 & & 0.827 \\
\hline \multicolumn{4}{|l|}{ Self-perceived Health (reference category=Poor) } \\
\hline Fair & -0.4312 & $* *$ & 0.650 \\
\hline Good & -0.7544 & $* * *$ & 0.470 \\
\hline Excellent & -1.1426 & $* * *$ & 0.319 \\
\hline
\end{tabular}




\begin{tabular}{lrll} 
Home Ownership & -0.6604 & $* * *$ & 0.517 \\
Have Credit Card Debt & 0.4641 & $* * *$ & 1.591 \\
Have Mortgage & 0.3651 & $* *$ & 1.441 \\
Have Purchase Loan & 1.7471 & $* * *$ & 5.738 \\
Have Vehicle Loan & -0.5215 & $* * *$ & 0.594 \\
Have Student Loan & 0.3100 & $* * *$ & 1.363 \\
Log (annual household income) & -0.0165 & & 0.984 \\
Log (financial assets) & -0.1432 & $* * *$ & 0.867 \\
Income Shock & 0.6021 & $* * *$ & 1.826 \\
Using Public Assistance & 0.2135 & & 1.238 \\
Concordance & $84.4 \%$ & & \\
Chi-sq test of likelihood ratio & 1998.9673 & $* * *$ & \\
\hline$*$
\end{tabular}

$* p<.05, * * p<.01, * * * p<.001$

Note: Sample size $=25,889$. Weighted analysis on data from 1992-2007 Surveys of Consumer Finance. 
Figure 1 Predicted Probabilities of Debt Delinquency over Life Cycle Stages

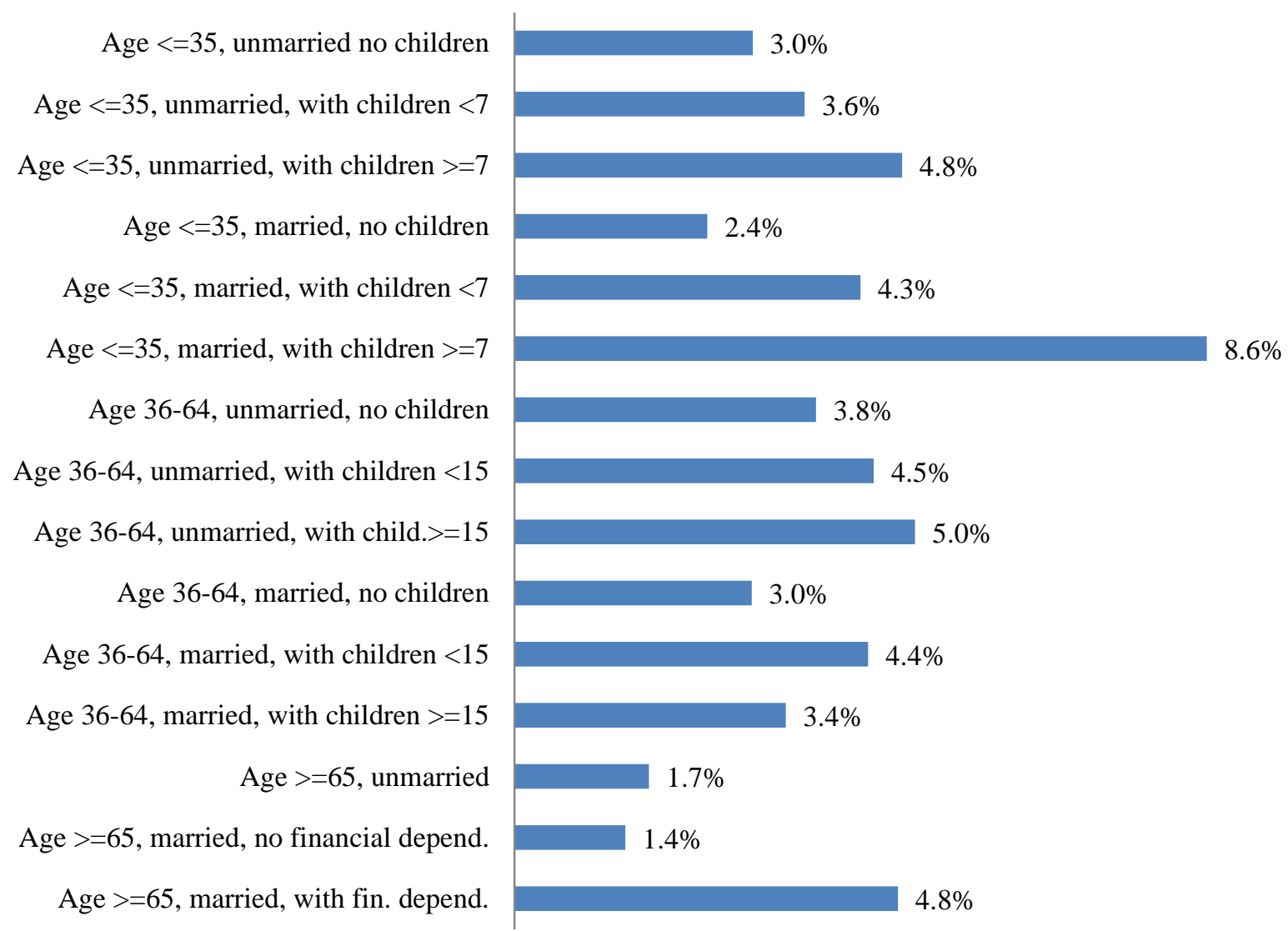

Note: the results are calculated based on the logistic results in Table 3, in which year=2001, education=high school, race=white, employment=wage earner, health=good, and mean values for other control variables. 
Figure 2 Debt Delinquency Risk Over A Hypothetical Path of Life Cycle Stages

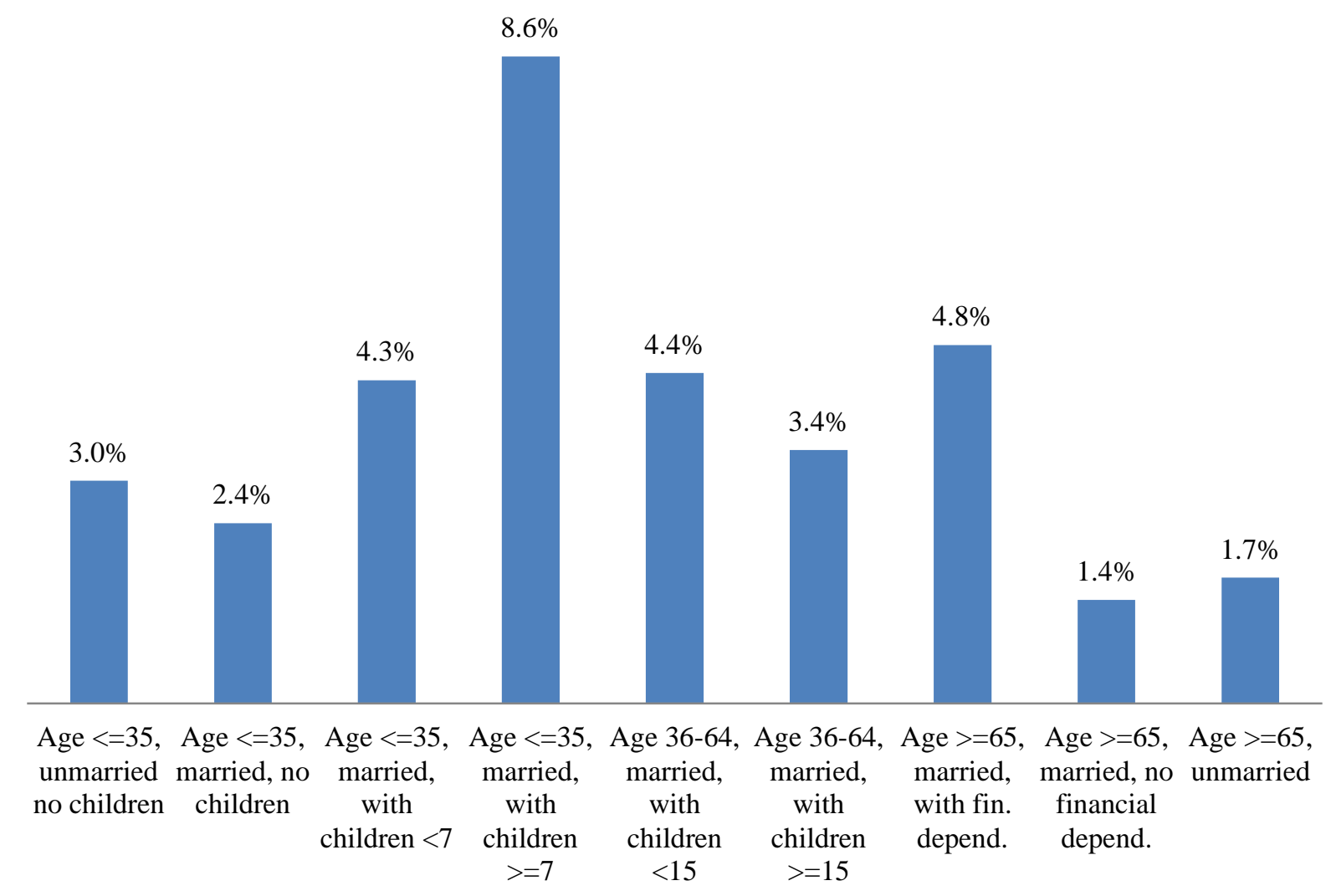


Figure 3 Debt Delinquency by Selected Age Comparisons

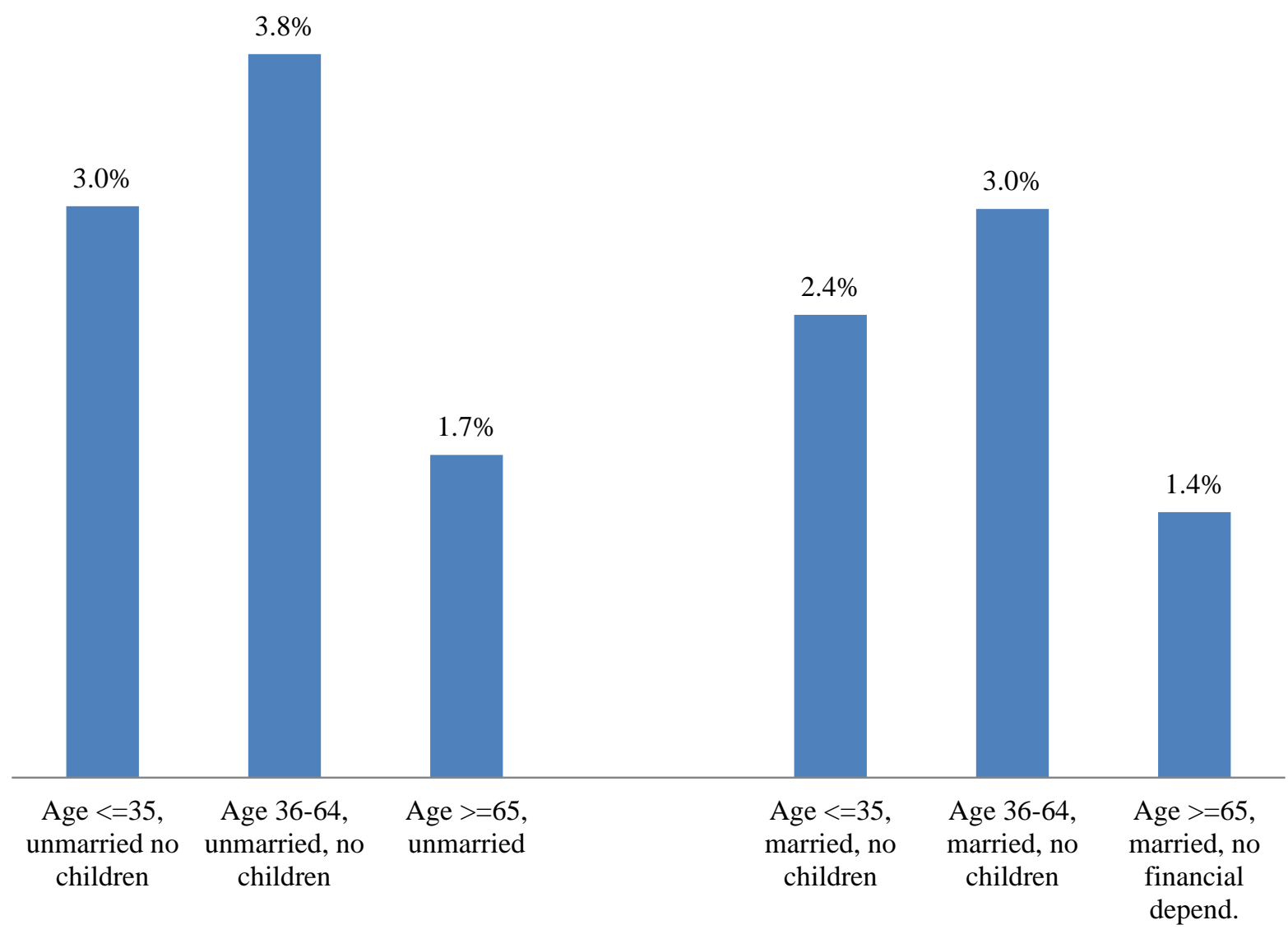


Figure 4 Debt Delinquency by Presence of Children Comparisons Among Age <35 Group

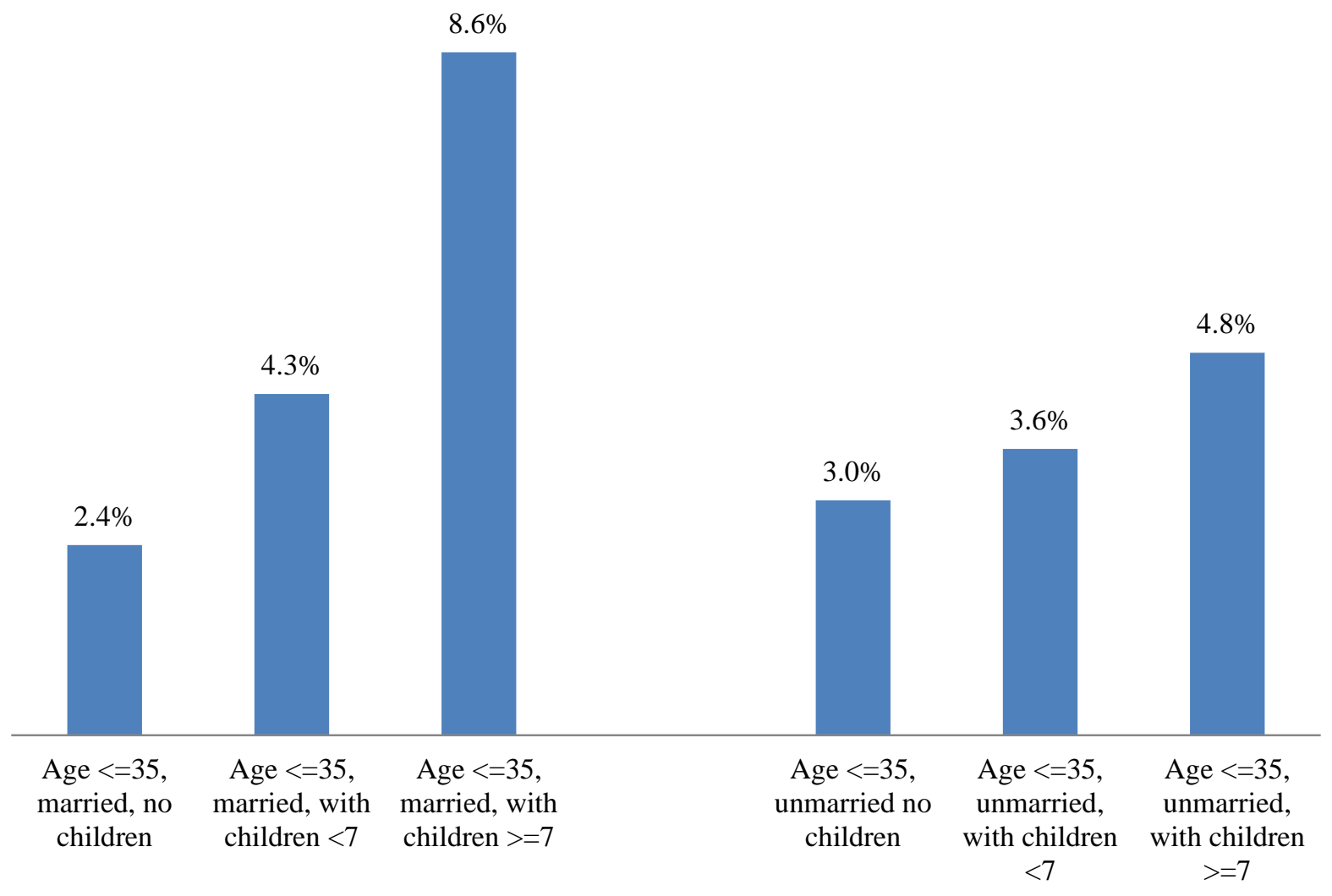


Figure 5 Debt Delinquency by Presence of Children Among Age 35-64 Group

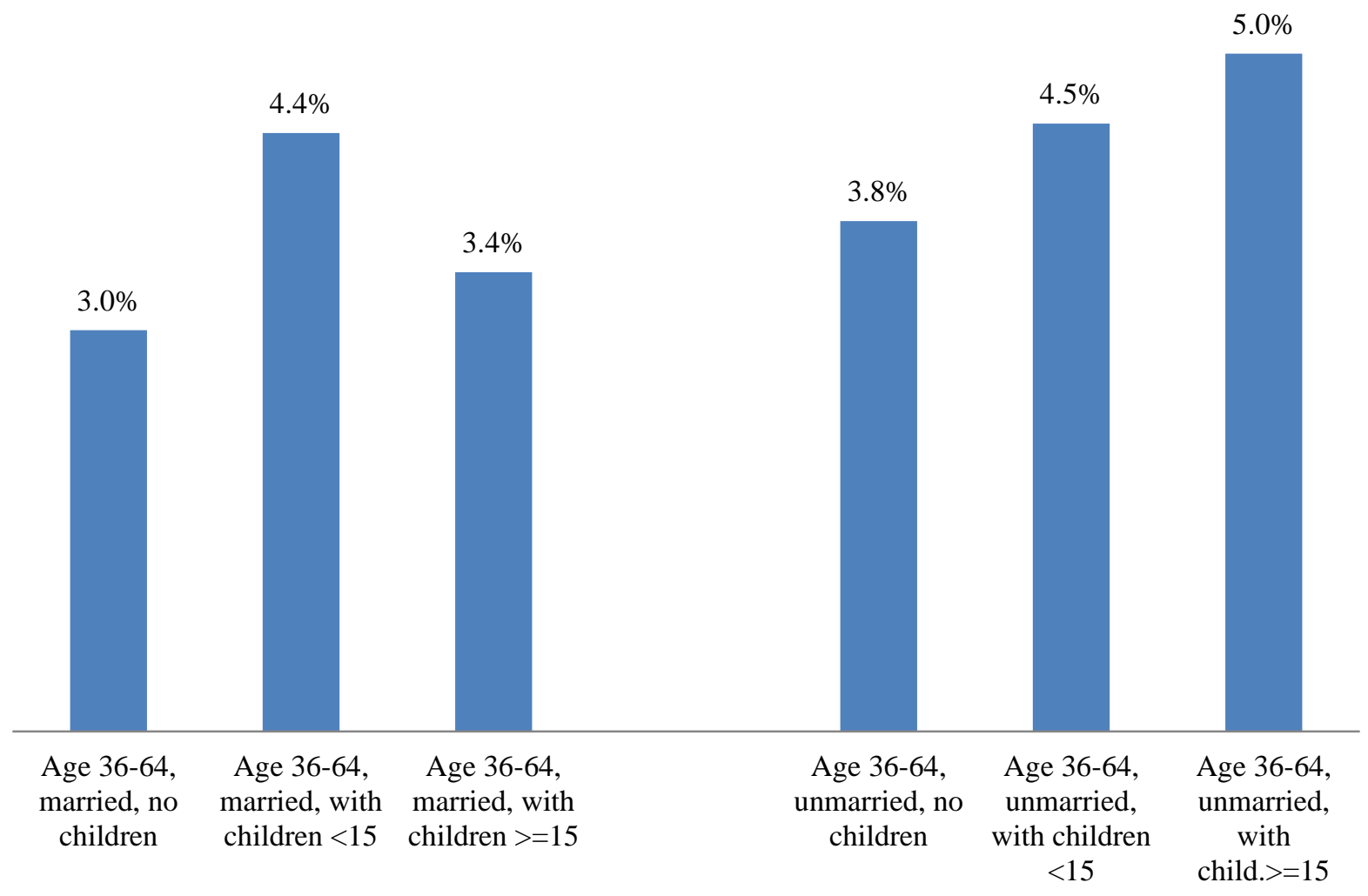


Figure 6 Debt Delinquency Risk by Age of Children

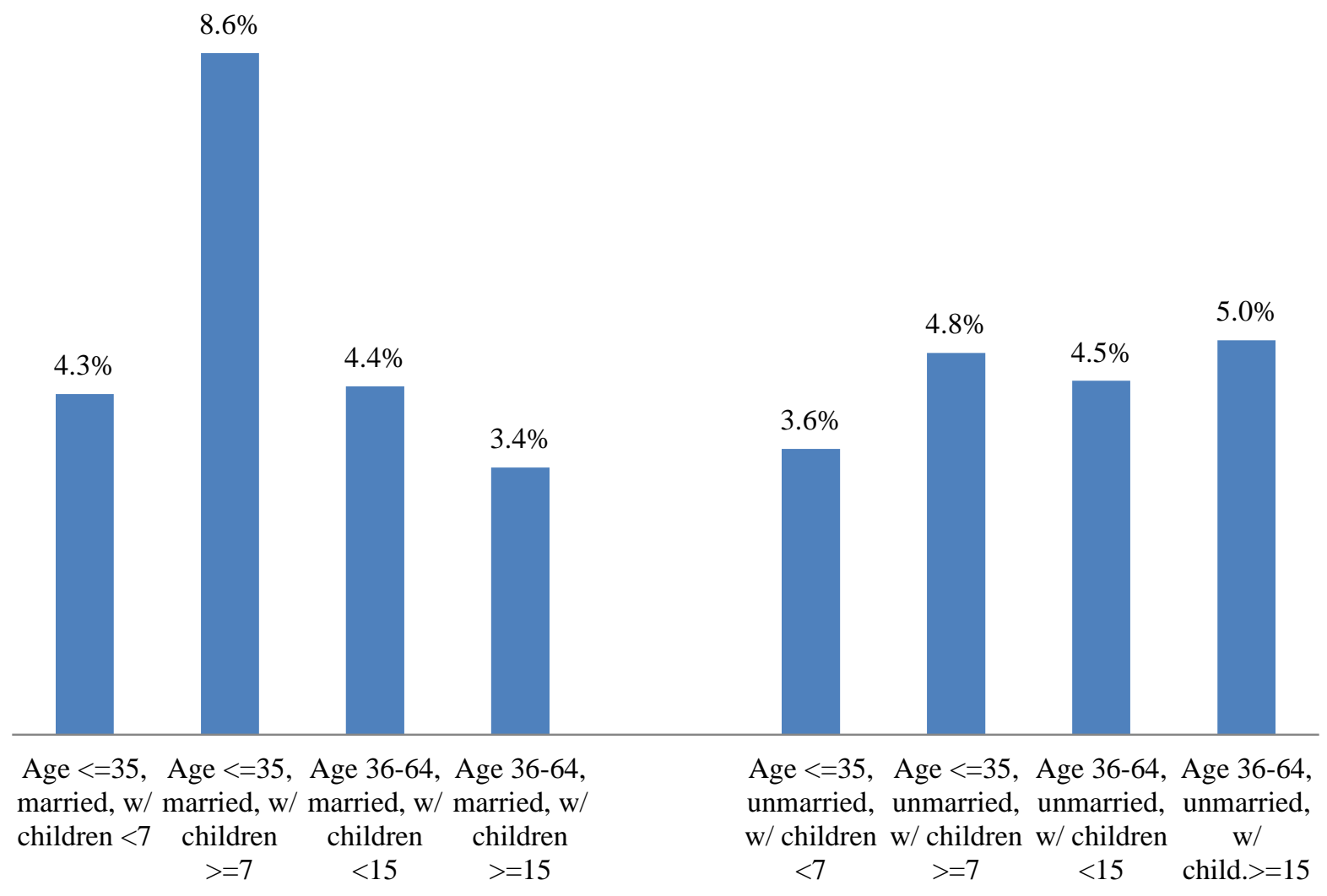


Figure 7 Debt Delinquency Risk by Marital Status

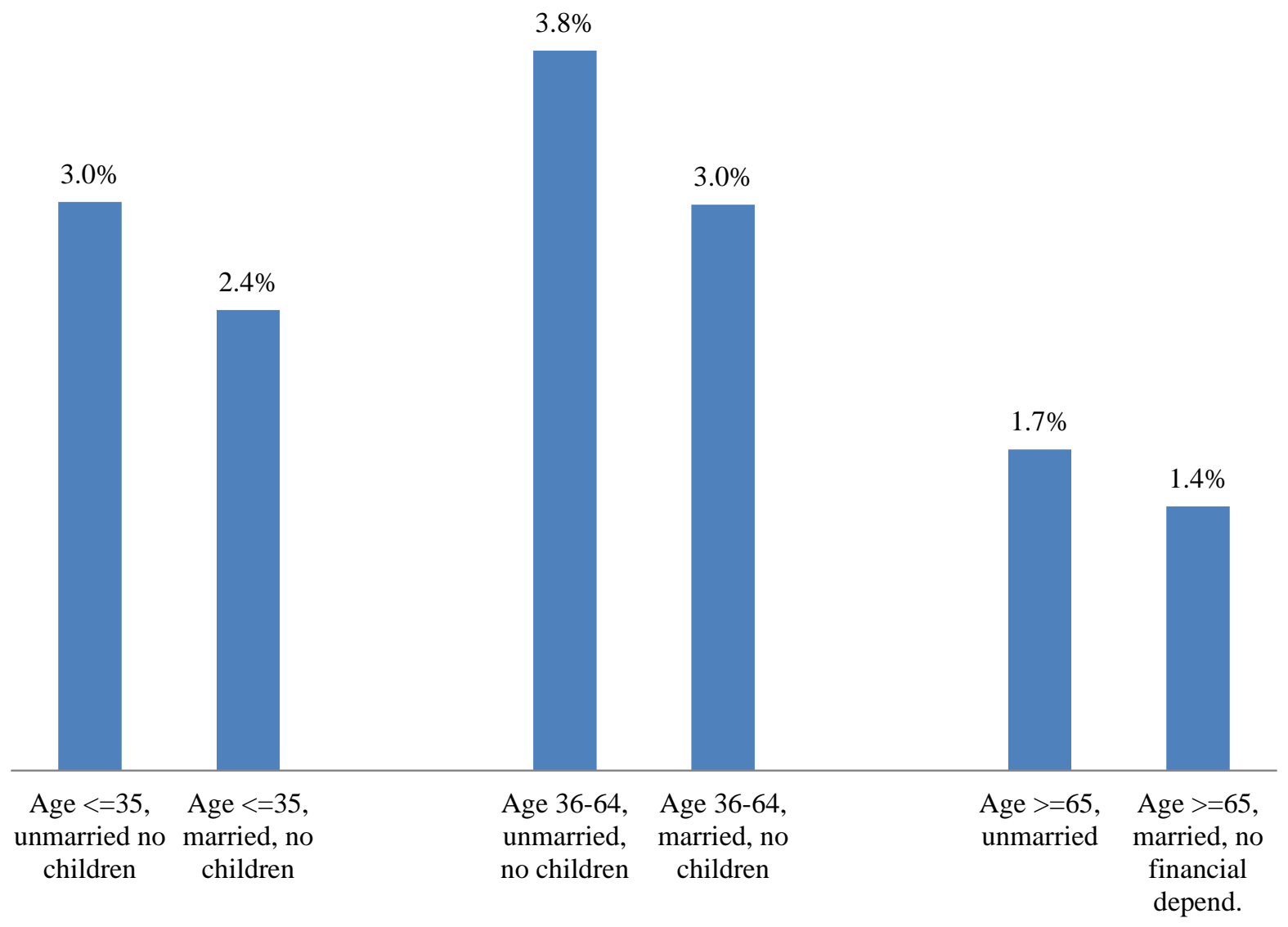

